$11-17-2017$

\title{
Living with the Liminal: Unwieldy Unknowns of Facilitating an Urban Education Cohort of Student Teachers
}

G. Sue Kasun

Georgia State University

Follow this and additional works at: https://newprairiepress.org/piper

Part of the Teacher Education and Professional Development Commons, and the Urban Education Commons

\section{Recommended Citation}

Kasun, G. S. (2017). Living with the Liminal: Unwieldy Unknowns of Facilitating an Urban Education Cohort of Student Teachers. Pedagogy \& (Im)Possibilities across Education Research (PIPER), 1 (1).

https://doi.org/10.4148/2576-5795.1003

This Article is brought to you for free and open access by New Prairie Press. It has been accepted for inclusion in Pedagogy \& (Im)Possibilities across Education Research (PIPER) by an authorized administrator of New Prairie Press. For more information, please contact cads@k-state.edu. 


\title{
Living with the Liminal: Unwieldy Unknowns of Facilitating an Urban Education Cohort of Student Teachers
}

\author{
Abstract \\ The field of education research often overlooks the importance of supervision of the student teaching \\ experience. In this article, I show how as a doctoral student with a focus on education for social justice, I \\ struggled in that role of student teacher supervisor. Despite the students being enrolled in an "urban \\ education" cohort, I felt my positioning was very liminal and perhaps counter-productive to the goal of \\ social justice. I provide reflections and concrete examples of how racism manifested in classrooms and \\ how the student teachers with whom I worked did and did not disrupt it, and how I often was unsure \\ about how to proceed. I also provide implications for educators and researchers.

\section{Concepts, Ideas, People} \\ Student Teaching, Pre-Service Teachers, Student Teacher Supervisor, Urban Education, Social Justice \\ Epistemologies, Methods, and Theories \\ Liminality, Critical Theory
}


I folded up my six feet of length into a red kindergarten-sized chair where I tried to observe the classroom as unobtrusively as possible, fulfilling my role and duty as a doctoral student preservice teacher supervisor. Monica (a pseudonym, as are all names used in this article) was in her final semester prior to completing her teaching degree and teaching about 25 kindergarten students, in the midst of one of my eight observations of her instruction for the semester. My fingers dutifully flew across the keyboard of my laptop as I took strict observational, supposedly non-subjective notes observing her behaviors. "Monica called on a boy who was sitting outside his carpet square. 'Crisscross applesauce,' she reminded him to sit with his legs crossed, in a somewhat monotonous tone," I wrote. The same boy, I noted, shifted again off his blue carpet square and pulled on a girl's pigtail.

Monica did not notice this and continued to try reading The very hungry caterpillar (Carle, 1969) to the students, using a sing-song - if not also falsely enthusiastic sounding - voice to describe how the caterpillar continued eating. Most of the students were not performing "on-task" behavior but looking around absently or engaging each other in clearly "off-task" behavior. I would later conference with her, as I did after each observation, trying to get her to consider the course readings about teaching and "classroom management" (a mandated course in which I also participated as a facilitator). I wondered to myself if I had any positive impact on Monica's teaching, if her students would learn much from her, if she cared much for children, if her role was a space-holder among perhaps leagues of teachers the students would be funneled toward throughout their 13 years of public education in our system.

\section{An introduction}

My wish is that this could be a story of the success of my activist work, one where I attest to the brilliance of my skills at changing perceptions of student teachers in droves toward utter transformation where their pedagogies become liberatory (Freire, 2008) and culturally relevant (Ladson-Billings, 2009). Indeed, my impact would be so "transformative" that my student teachers would eventually lead their charges into helping all their students be truly active citizens who transform our governments into true democracies where all citizens are active and valuedor so goes the starry-eyed dreaming of aspirations toward social transformation. When I work with students, prepare them to do a craft, a project I believe in, I know I have the tools to help them grow in that project, to help myself grow in our connected journeys. I believe in public education's transformative potential; like so many others, I am committing my life's work to it.

I want to say that my work with twenty student teachers in a cohort specifically devoted to being an "urban" education cohort at a large research university was transformative (Author, 2013). Yet, this isn't a story of activist success, but rather a story about my liminal positioning and my liminal sense about the work I did. By liminal, I mean the sense of unknowing, in-betweenness of not knowing entirely what my role was, its impact, and the uncertain nature of my work with the students. I use liminality to frame my work with the cohort in two ambiguous roles: as vulnerable observer and possibly as policing enforcer. I call into question the outcomes of such 
liminal work in the larger project of attempting to work toward social justice in education, especially as we consider the production of teachers in the current system of teacher education programs.

Approaching supervision of student teachers, for me, provokes senses of ambiguity and ambivalences. It is in that space of unknowns, among so many federal and state-mandated givens, that I bear witness to what has and has not been transformed in the future teacher's understanding about what the project of education means, especially in terms of how it may be used to transform society. Presently, as tenure-track faculty in teacher education, I have mostly avoided this work, in some small part due to the anxiety-provoking nature of it. To be clear, the anxiety-provoking part is knowing that the flocks of teachers we train often do very little to help interrupt cycles of inequality and structural injustices of racism, classism, sexism, and others "isms." At the point of student teaching, the supervisor is subject to the structures surrounding performance expectations of the student teachers. As an educator of teachers, I find it far more comfortable to work within the domain of a proscribed course where I (ostensibly) have the final determinations on the brackets of what is and is not accounted for in my teaching and the students' learning, as opposed to a battery of state-approved "observable" functions student teachers are supposed to meet, functions generally nested in behavioristic models. My training in sociocultural theory of education, by that point, had created deep reservations regarding the influence of behaviorism in education and how it would likely not help create innate motivations among the students (Vygotsky, 1978). The student teachers I discuss in this article were responsible for meeting over sixty performance standards toward being licensed to teach-standards I cannot say I entirely stood beside nor agreed were the most important and necessary ones toward students' eventual success as teachers.

This article is a reflection on how this work is so often liminal, or situated in the in-betweenness of what may and may not be achieved by the supervisor among student teachers. It is based on my work when I was a doctoral student supervising many student teachers at a large, researchintensive university in an "urban education" cohort. I provide examples of several liminal moments and then engage ideas regarding post-oppositional politics. I believe we may thus consider ways we may work on interrupting assumptions held by student teachers as well as acknowledging limitations of structures and systems already in place toward improving them.

\section{Background}

Research in urban teacher education tends to deal with issues related to retention, attrition, and teacher education program design (Donaldson, 2009; Warshauer Freedman \& Appleman, 2009). These researchers usually recognize that students in urban schools are underserved and need teachers who are more likely to stay as teachers rather than to leave; currently, teacher attrition is much higher in urban schools than in non-urban schools. Little research discusses how those who facilitate the work of apprentice teachers in urban educational settings impact student teachers in their student teaching phase, and less so regarding the efforts toward social justice, which many 
teacher preparation programs claim as part of their mission statements. In this paper, I trouble my own efforts to best prepare apprentice teachers in their final semester of apprentice teaching.

"Urban" education programs have been developed in United States universities as a conventional response to the so-called "achievement gap" (Ladson-Billings, 2006) of academic performance disparities among racially and economically disparate populations. While one may initially use the term "urban" to describe proximity to a city's center, it is now often used to describe the makeup of students (usually students of color) and the tensions surrounding the education of these students (McClafferty, Torres, \& Mitchell, 2000) in a dominant society which remains unengaged with its histories of colonization and whiteness (Leonardo, 2009). One response to troubling the sense of the achievement gap is to invoke Ladson-Billings's (2006) inversion toward the sense of the "education debt" owed to the historically marginalized students and to work inside the system of those urban education cohorts in dismantling a hegemony which perpetuates that very achievement gap. Nonetheless, attempting to be an activist within the system (Urrieta, 2009) can be transformative, complicated and/or have unforeseen consequences.

\section{Theorizing, keeping track of the work}

Liminality is a stage or space of in-betweenness, of being "betwixt and between" (Turner, 1969). Turner argues that those in liminal stages have ambiguous status and power roles (Turner, 1977); by virtue of these shifts, people can assume new senses and power and different roles which can be freeing and generative of change. He begins to theorize his work on liminality from his years researching the Ndembu people of Africa and their ritual practices, noticing that during rituals, participants experienced liminality because their roles were shifting and senses of power ambiguous, in, for example, ceremonies related to adolescence or pregnancy (Turner, 1969). He notes that rites of passage are productive in allowing individuals to experience moments that are formative in their development and shifting into new roles in life. Turner's work, at the time, was revolutionary in focusing on the sense of the unknowable-in-the-moment as opposed to using a researcher's lens to name the knowable. He later theorizes that all societies have experiences of liminality (Turner, 1982).

Anzaldúa (1987) also explores the liminal in her work on Borderlands, as a lesbian poet and theorist hailing from South Texas and being of Mexican-origin, and later in re-emphasizing the spiritual and psychological components of her concept of nepantla (2002), or being in-between. She uses the Nahuatl word of "nepantla" to help resituate the sense of liminal by hooking into ancient wisdoms of practice and also privileging a term which can be loaded beyond the term "liminal." Indeed, the term nepantla provides recognition of a space of possibility. Anzaldúa takes the term and then turns it toward the one who can be a "nepantlera" who works toward social transformation, while recognizing such transformation always starts with the self (2002). Anzaldúa (2002) explains, "And nepantla is the only space where change happens...change... takes perseverance, creative ingenuity, and acts of love" (p. 574). Where Turner emphasized the importance of the collective, such as rites of passage, in how people might be impacted by the 
liminal, Anzaldúa theorized, in addition, with a focus on the individual's space of agency to impact the collective, especially through the notion of love, often as love toward self, first.

While research shows that student teachers' roles are liminal in their ambiguous space of being neither fully teacher nor fully student (Head, 1992), it seems there is little exploration of the role of the facilitator who works with student teachers as liminal, perhaps a reflection of how little this idea is engaged in Western discourse in general. Additionally, there is little research regarding the role of doctoral students' work with student teachers as mentors. I argue that my role as a facilitator was also liminal as not-yet-PhD and not the cohort supervisor. I am also left in a liminal state regarding whether the people with whom I worked are guided more toward social justice.

In this urban education cohort, there were 22 student teachers. Just over half were white, the others from multiple backgrounds, including African American, Latinx, and Asian. They had been together for a full year, and I started facilitating during their last semester before their graduation. Some students chose to be in this cohort based on a paragraph they had read in a university description; others were simply placed there. Being a facilitator would mean I would be liminal--between the university supervisor/faculty, who taught the students a course on classroom management, which I would help facilitate (see figure below) and the school's cooperating teacher where students were placed.

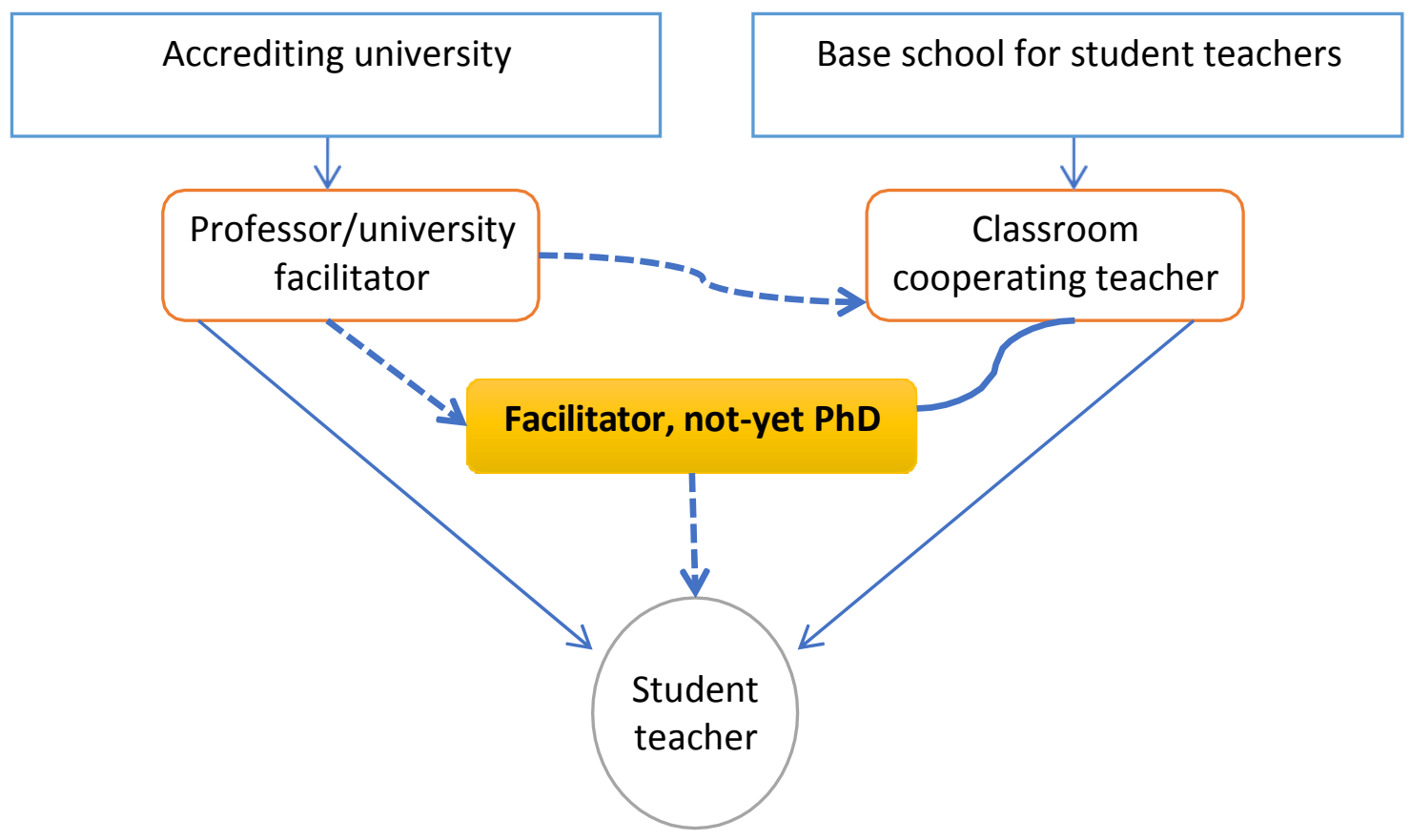

Figure 1.

This was the third and final course in a series the faculty member taught in three semesters as their cohort supervisor. The white supervising professor, a woman who had been involved in activist work inside and outside education since the 1960s, included readings and discussion 
surrounding students of color and "urban" education from critical educators (Banks \& McGee Banks, 2010; Delpit, 2006; Lee, 2005; Michie, 2005; Valenzuela, 1999). I would also be liminal among 10 of the students doing their student teaching in three "urban" elementary schools, and their cooperating teachers at these schools. I conducted eight observations of each of these ten student teachers ranging from 30 to 90 minutes and then held follow-up conferences with each student. I also held final evaluation meetings with each student where I had the ultimate determination in each of the 102 university-mandated criteria upon which they were judged.

I resolved to push as much as I could to disrupt what Gramsci and Kumashiro call common-sense (Crehan, 2002; Kumashiro, 2004), in this case, notions surrounding "urban" students, typically from a deficit lens, viewing urban children in need of saving (Valencia, 1997). I hoped to help student teachers to be as effective as possible. Leaning into Ladson-Billings' sense of culturally relevant pedagogy as my gold standard--academic achievement/student learning, cultural competence, and socio-political consciousness, I did the following: 1) pushed student teachers to help their students learn with the highest rigor; 2) gained a sense of the students with whom they were working and the diverse backgrounds from which they come; and, 3) worked toward critiquing an inequitable system around them in their instruction. I knew it would be a challenge, particularly in the schools where my students were placed, Title I schools where most of the children qualified for free and reduced lunch and often spoke more than one language. Most students at these specific schools were Latinx; a small percentage were African American, and there were occasionally one to two white students in some classrooms.

I kept a running record of my more than eighty observations of student teachers as well as followup conferences. I also journaled about my experiences (Emerson, 1995), focusing on contexts and the situatedness of experiences in those contexts described above. After coding of observations and conferences based on my observations with the student teachers, I sorted concepts which I find troubling into several themes related to my liminal positioning as facilitator. I caution these concepts are only constructs to try to frame the sense of my work; I trouble each in turn as I demonstrate my positioning and weave in my sense of whether I was facilitating student teachers' emerging sense of culturally relevant pedagogy. I begin with the sense of being a liminal observer and then shift toward whether I was perceived as policing enforcer.

\section{Liminal observer}

I was a liminal observer in the classrooms, one who was forced to remain largely silent and attempt to soak in what was happening with all senses open. Maintaining an openness when I often felt judgments rising, when I was otherwise used to intervening to try to correct problemsthis required a painful kind of vulnerability and frustration. I experienced a great sense of vulnerability in that liminality, as I attempted to remove my guard to imbue my work. I found myself emotionally attached in some ways, often co-identifying with those I observed, from the young children in classrooms to the student teachers. I found myself struggling, hurting, frustrated, and at times elated by my observations in both the student teaching and in the course 
the student teachers took. I felt conflicted about my role and how much I should show my vulnerability in the daily pressures of classroom teaching I observed. The tears in my eyes, for so many reasons, would dry quickly as I shifted into steeling myself toward the work I felt I was supposed to do, based upon my convictions about the possibilities of education and not so much the formal professional obligations of the task - all the check-boxes of observations and formal requirements of the university and the state.

On several observations of student teachers in these urban classrooms, I was upset to see the kind of instruction students received. Why were the students, the ones Ladson-Billings portrays as being on the receiving end of the "educational debt," of public education (Ladson-Billings, 2006) receiving so much low-level instruction, comprehension and rote memory learning in so many classrooms? I was able to share many instructional strategies and encourage student teachers to adapt higher-level thinking activities, but there were also times when I wasn't sure my advice penetrated. I often wondered why the children had to be subjected year after year to so many carrot-and-stick behavior systems, carefully elaborated in ever-popular behavioristic tomes such as Wong \& Wong's The First Days of School (2004). Was bearing witness to behaviorism something I was ok with not interrupting? And even when I did attempt to interrupt, did it ever undo the years of behaviorism the student teachers had endured and the nods toward why it was useful to engage formally from the institution for which I worked? These questions remain, even years later.

With the student teachers I observed, I explicitly connected the research about the positioning of black and brown students, especially boys, as eventual criminals and on the path to dropping out (Lewis, 2005) and as part of the "school-to-prison pipeline" (Wald \& Losen, 2003) each time these children were disciplined for behavior that didn't seem particularly offensive to me. Could I blame children who wanted to move and wiggle, especially when the instruction - often based on mandated curriculum - was dry? How much can a child force himself to do abstract problem after problem related to place value on worksheet after worksheet?

For instance, with Lorena, a Latina pre-service teacher, I could later conference about how the only white boy in her classroom was actually provoking an African American pre-kinder student during carpet time, but she hadn't seen that he was the instigator. Instead, like so much research shows about the positioning of African American boys, she was positioning him as the problem. We had this difficult conversation, and she was more sensitive about how she worked with the African American student afterwards. Weeks later, I would learn that she and her classroom cooperating teacher had spent a great deal of time preparing for Latinx-oriented events, including the posada, a Mexican-oriented Christmas celebration (surely reconfigured to be inclusive of nonChristians) that the school celebrated as well as the ways they involved family members in preparation. I wondered about their quiet work, the very stuff I had been getting red-faced about in the student teachers' weekly classes, how they needed to connect with families on a humane level, and yet I didn't understand why Lorena had never discussed the posada with the class. I 
would be left with a liminal sense of effectiveness and ability to understand even the moments worthy of celebration in Lorena's becoming a teacher.

My liminal observer role was also present in the university class the 22 student teachers took. Despite the university supervisor's genuine encouragement of my classroom contributions, I would always wonder about my positioning to do so. One day, I asked the student teachers to consider the posture of the children at one elementary school as they walked down the halls. What did it mean to have children walk with their hands behind their backs? Some students tried to make sense of how that could possibly be ok; others were adamantly disgusted with the practice which so resembles prisoners walking in form. Was the university faculty supervisor comfortable with my line of questioning? Was I pushing boundaries with which maybe she was not comfortable as a former principal who may have also advocated allowing students to walk with hands hooked behind their backs? Did I need to allow that concern to bother me?

On another occasion, the professor shared the analogy of white privilege being the large supermarket available to whites with easy access, that people of color showed up at the door and it wouldn't open for them. I struggled, knowing that people of color have more agency than this, and yet I wasn't sure about my own positioning as a white woman speaking up. How would the women of color in the course feel? Was it my place? I spoke up:

People of color have been forced by systemic racism to be resourceful. That means they often find a way around the door, through a tunnel, through a backdoor, through a basement. And upon entrance, they find creative things to do with the ingredients they do access. And sometimes, people of color have had enough of the white person's store. They say, 'fuck your store' and just don't bother.

Behind me I heard two African American students say, "Mmm hmm" as I finished, and, the professor thanked me for the contribution and even extended it. The next week, the same two students shared a book project about Lisa Delpit's Other People's Children (2006), and the more outspoken of the two would eventually end up crying before the entire group, imploring them, "Please, you just don't know what it's like to be black; it's so hard, and I get so tired fighting. You've got to be a good teacher and understand the children you work with." Perhaps we had begun the work of a critique of why education seems so broken in this country. I cried while she spoke, and I cried several more times that day. I emailed her later and thanked her so much for being vulnerable with the group and instructing us.

There were also moments of what seemed like effective instruction where I'm not sure how much I added by observing, perhaps only validation about the events as they unfolded. In another student teacher's $2^{\text {nd }}$ grade classroom, Taylor's (a pseudonym) students were invited to kiss their brains in celebration of their good thinking when they showed examples of how they made inferences about states of matter. I remember being thrilled at how articulate those seven year olds were. Similar to another student teacher's kindergarten classroom, the children used 
complete sentences and academic vocabulary in meaningful ways. These student teachers had followed their cooperating teachers' leads in providing what seemed to me like meaningful instruction where students were engaged in work they genuinely cared about.

\section{Policing enforcer}

Aside from the vulnerable observer who spent a lot of time hiding and shedding tears, I fear I was also considered the policing enforcer of my brand of education for social justice, one that is not comfortable seeing the current inequalities in the larger U.S. society reproduced through K-12 education, including oppressions related to race, class, gender, religious, and sexual orientation. For me, social justice education requires praxis--a critical reflection and continual adjustments on the practices of both the individual teacher's instruction as well as the historical educational and social systems of which one is a part (Cochran-Smith, 2008). I can't know precisely how the student teachers interpreted my comments during class or the ten with whom I worked most closely in observations of their classrooms. I do know that most of the student teachers were uncomfortable with my comments in class. While the professor tended to help the students bond with each other through community-building activities, I tended to challenge students to be uncomfortable about their assumptions about privilege and their roles as teachers. Early in the fall semester, I told my group of ten student teachers who I was observing, "Look, I don't mean to feel like the police to you, but if I see things that really don't match up with being culturally relevant, we're going to talk about it."

Later in the semester, in two separate grade levels, I watched student teachers read the book $O w l$ Moon (Yolen, 1987) in its entirety. In terms of being culturally relevant, nothing could be much further. In the Southwest where we were located, there is usually very little snow; in Owl Moon, a white boy and his white father tromp through page after page of the stuff. To those two students I explained that the book could be used, but that it needed to be used among many other texts which would resonate further with the communities of students they served. Yet I couldn't force them to do that, and I wasn't the professor, in a position to change the class subject from classroom management to at least culturally responsive texts (Gay, 2000).

One event in particular stands out as problematic, liminal, and likely running counter to the project of social justice. During my rounds of observations toward the end of the semester, I entered a student teacher's second grade classroom as they were beginning a Native American unit. It was approaching Thanksgiving, and lumping Native Americans into four geographic regions for study, as she had, was problematic. The unit had been co-planned by two second grade teachers who took pride in their work and care about their students; the student teachers mostly followed the unit plans they had been given. Nonetheless, this did not mean, to me, that I wouldn't object to instruction I found beyond the scope of being, at the very least, politically neutral.

I entered the room and found each of about 17 children wearing brown construction-paper headbands with various numbers of green and blue feathers attached to the top. I wanted to walk 
out and ignore it; I felt an icy sensation that what was happening was messy and perhaps beyond the scope of my effectiveness. Something that felt like conscience told me to stay. I watched the student teacher have students write pretend legends about how they got their names and use the feathers as, what she would later tell me was a weeklong "behavior management strategy" (harkening back to my earlier concerns about why behaviorism was or was not a useful approach to teaching). I heard the student teacher mention in the class that the children could "earn feathers" for good behavior. The one African American male youth in the class, who also was known to have the worst behavior, had the least amount of feathers. Because she was at a point of full-day instruction, I could not conference with her that day, so I sent her my feedback and a short chapter titled, “'No, I didn't make it rain last night': Or rethinking how we teach about First Americans" (Rains, 2001), remarking about the instructional activity, and mentioning how I found the headbands and feathers inappropriate and essentializing all Native Americans as well as potentially trivializing their symbolic usage among the tribes who do still use them today.

Two days later I spoke with her, and up until that point, our relationship had been cordial. She told me she felt defensive, and I realized I probably completely lost the chance to maintain a form of communication with her in which she could learn from me. Later, in a strange string of events whose workings remain unknown to me, the two second grade cooperating teachers became very angry that I critiqued an activity in their unit, and I heard about it from one of them. That cooperating teacher eventually emailed the professor I worked for and the principal of the school insisting on a meeting with me. He had felt attacked. His principal would question my professor upon what grounds I had been hired. And I would feel very misunderstood, frustrated, and recognize that potentially, instead of succeeding in getting a new student teacher to develop a more nuanced sense of Native American cultures, I had probably further entrenched multiple people's ideas about Native Americans, not to mention the arrogance of soon-to-be-PhDs. Again, I cannot know for sure the thoughts of those who I had upset, and that is part of what makes this both liminal and problematic.

\section{Discussion}

Overall, seven out of ten student teachers I observed and conferenced with grew in ways that pushed their thinking on social justice and urban education; at least that was what they told me in our final evaluation conference. I am not certain of that outcome, and it echoes the liminal sense of the work I did. Among the ten in-service classroom cooperating teachers with whom I worked, I suspect, in my liminal positioning. that I may have had a positive impact on three. These were all Latina women who spoke Spanish, who, through conversation, I recognized had very critical views of U.S. public education. My positive impact, if any at all, was only in reinforcing their good work by explicitly discussing racial and political issues with them and supporting their work. I did not apply a survey to them, though no doubt the university has collected survey data from the student teachers about their experiences. I have seen the questions and know they were not asking questions about social justice or equality. Taken as a whole, I'm scoring about 50\%. That's an F in most schools, and I'm not comfortable with it. It's also in many ways an over-simplified 
depiction of my work. Of course there's no way for me to fully understand my impact, particularly with my liminal positioning as an in-between facilitator of this urban education cohort.

I don't believe the facilitator, in his or her liminal positioning between supervisor and the student teachers, can resolve these tensions. However, I offer suggestions to help support the facilitator's role. It would be helpful to simply know in advance that their work will be liminal and ambiguous, and I hope this article will help convey that message. Even in an urban education cohort, highminded activist goals toward helping students achieve social justice will likely be frustrated and frustrating. A thoughtful facilitator may vacillate at times between the role of liminal observer and perhaps as policing enforcer, not sure how others perceive the facilitator's role. At the same time, there can be additional roles and subjectivities that may emerge from this liminal positioning. It could be helpful for the facilitator to be able to express her sense of liminality to the cohort of student teachers so that they might have both more empathy and hopefully respect for the work the facilitator does with them. It would also help the faculty member better support the doctoral student facilitator's work.

The liminal positioning of the facilitator is also a space of potential. There is a space of play available to the facilitator which is less available to the supervising professor precisely because the role is less determined and fixed. Thus, the facilitator may be able to engage in potentially difficult conversations more easily than the supervisor, for instance, depending on the situation. This could be a space where the facilitator can assume a role of attempting to help people move toward "post-oppositional politics" (Keating, 2013) wherein they understand each other, and especially the situated contexts of the K-12 students, without judgment but toward improved social conditions. This can represent a shift away from "policing enforcer" toward bridge-builder (Kasun, 2015) among student teachers and the facilitator, if not also the university faculty member. The sense of policing enforcer was always ungratifying if not also ethically disturbing. While it is possible I was "right" about my work, I may have served to do more harm than good among some of the student teachers. In this sense, finding spaces for bridges then becomes essential work. It requires, without question, a reflexivity and humility on the part of the student facilitator. For instance, the doctoral student is, arguably, less linked to official (and often limiting) policy and may be able to speak more from the heart about student teachers' work than with considerations more situated in protecting the university or adhering to state-mandated policies (which are, of course, important considerations).

The role of the doctoral student facilitator begs additional questions. To what extent is the good will of the graduate student being exploited in her role as facilitator? To what extent are the student teachers subject to both the good or bad will and the perhaps uneven preparation of the facilitator? Is it even possible for the social-justice oriented facilitator to disrupt the socially reproductive nature of many (if not most) teacher education programs? 
For those who design education cohorts and student teachers' programs of study, it will be helpful to be clear about their expectations, particularly if programs have an agenda for social justice, as an increasing number of programs do in the U.S. We need to be clear about what social justice means and how we intend to achieve it through work in education. If, among their objectives, is successful work in urban contexts, education cohort designers could adopt some clear guidelines that the students can also articulate and work with in their placement as teachers. One starting point could be using Ladson-Billings's (2009) criteria for culturally relevant pedagogy instead of the 102 point observation evaluation scale that was mandated in all cohorts at that particular university. In my role as "policing enforcer," I sensed I was consistently on the defensive. Social justice work in education is an additive process, not one that should be perceived as subtractive. The discomforts of confronting the realities which make social justice work necessary need to become normalized experiences of student teachers; surely they will spend their careers confronting these injustices and using their positioning as teachers to confront these injustices. Adopting Ladson-Billings's criteria would allow for a culturally relevant framework of reference to use as a baseline of expectations which could help make difficult conversations less contentious and less "policing." Similarly, looking toward finding a space of commonality among all parties can help shift away from a need or sense of being "right" toward one of both engaging and building community. This latter point is one I am shifting toward in my continued thinking on social justice. Justice is not necessarily righting wrongs but creating the so often liminal space of love where multiple opportunities toward growth and creation might flourish.

Finally, there is a critical need to further explore the roles of those who work with student teachers in the field. These are the individuals who may have some of the greatest impact on future teachers, as they are the ones who work most closely with student teachers, aside from their cooperating teachers. They are supposed to be the critical bridge between theory and practice. The liminal sense of some that work should be taken into further consideration in future work. 


\section{References}

Anzaldúa, G. E. (1987). Borderlands/La frontera: The new Mestiza. San Francisco: Aunt Lute.

Anzaldúa, G. E. (2002). now let us shift... the path of conocimiento... inner work, public acts. In G. E. Anzaldúa \& A. Keating (Eds.), This bridge we call home: Radical visions for transformation (pp. 540-578). New York: Routledge.

Banks, J. A., \& McGee Banks, C. A. (Eds.). (2010). Multicultural education: Issues and perspectives (7th ed.). Hoboken, NJ: John Wiley \& Sons, Inc.

Carle, E. (1969). The very hungry caterpillar. New York: Philemon Press.

Cochran-Smith, M. (2008). Toward a theory of teacher education for social justice. Paper presented at the American Educational Reseach Association.

Crehan, K. (2002). Gramsci, culture and anthroplogy. Berkeley: University of California Press.

Delpit, L. (2006). Other people's children: Cultural conflict in the classroom. New York: The New Press.

Donaldson, M. L. (2009). Into--and out of--city schools: The retention of teachers prepared for urban settings. Equity \& Excellence in Education, 42(3), 347-370.

Elenes, C. A. (2001). Transformando fronteras: Chicana feminist transformative pedagogies. Qualitative Studies in Education, 14(5), 689-702.

Emerson, R., Fretz, R., \& Snow, L. (1995). Writing Ethnographic Field Notes. Chicago: University of Chicago Press.

Freire, P. (2008). Pedagogy of the oppressed (M. Bergman Ramos, Trans. 30th Anniversary ed.). New York: Continuum.

Gay, G. (2000). Culturally responsive teaching: Theory, research \& practice. New York: Teachers College Press.

Head, F. A. (1992). Student teaching as initiation into the teaching profession. Anthropology \& Education Quarterly, 23(2), 89-107.

Kasun, G. S. (2015). Teacher education Nepantlera work: Connecting cracks-betweenworlds with Mormon university students. International Journal of Multicultural Education, 17(3), 91-106. doi:http://dx.doi.org/10.18251/ijme.v17i3.1003

Keating, A. (2013). Transformation now! Toward a post-oppositional politics of change. Urbana: University of Illinois Press.

Kumashiro, K. (2004). Against common sense: Teaching and learning toward social justice. New York: Routledge.

Ladson-Billings, G. (2006). From the achievement gap to the education debt: Understanding achievement in U.S. schools. Educational Researcher, 35(7), 3-12.

Ladson-Billings, G. (2009). The dreamkeepers: Successful teaching of African American children (2nd ed.). San Francisco: Jossey-Bass.

Lee, S. J. (2005). Up against whiteness: Race, school, and immigrant youth. New York: Teachers College Press.

Leonardo, Z. (2009). Race, whiteness, and education. New York: Routledge. 
Lewis, A. (2005). Race in the schoolyard: Negotiating the color line in classrooms and communities. New Brunswick, NJ: Rutgers University Press.

McClafferty, K. A., Torres, C. A., \& Mitchell, T. R. (2000). Challenges of the new sociologyof education. In K. A. McClafferty, C. A. Torres \& T. R. Mitchell (Eds.), Challenges of urban education: Sociological perspectives for the next century (pp. 3-18). Albany: State University of New York.

Michie, G. (2005). See you when we get there: Teaching for change in urban schools. New York: Teachers College Press.

Rains, F. V. (2001). 'No, I didn't make it rain last night': Or rethinking how we teach about First Americans. In S. Steinberg (Ed.), Mulit/Intercultural conversations: A reader. New York: Peter Lang Press.

Turner, V. W. (1969). The ritual process. Chicago: Aldine Publishing Company.

Turner, V. W. (1977). Variations on a theme of liminality. In S. F. Moore \& B. G. Myeroff (Eds.), Secular ritual (pp. 36-52). Assen/Amsterdam: Van Gorcum.

Turner, V. W. (1982). Liminal to liminoid, in play, flow, and ritual: An essay in comparative symbology. From ritual to theatre: The human seriousness of play (pp. 20-60). New York: PAJ Publications.

Valencia, R. E. (1997). The evolution of deficit thinking: Educational thought and practice. London: Routledge.

Valenzuela, A. (1999). Subtractive schooling: U.S. Mexican youth and the politics of caring. Albany, NY: State University of New York Press.

Vygotsky, L. S. (1978). Mind in society: The development of higher psychological processes. Cambridge: Harvard University Press.

Wald, J., \& Losen, D. F. (2003). Defining and redirecting a school-to-prison pipeline. New Directions for Youth Development (99), 9-15.

Warshauer Freedman, S., \& Appleman, D. (2009). "In it for the long haul": How teacher education can contribute to teacher retention in high-poverty, urban schools. Journal of Teacher Education, 60(3), 323-337.

Wong, H. K., \& Wong, R. T. (2004). The first days of school: How to be a highly effective teacher. Mountain View, CA: Harry K. Wong Publications, Inc.

Yolen, J. (1987). Owl Moon. Philomel Books. 